\title{
Current Perspectives of Residual Ridge Resorption: Pathological Activation of Oral Barrier Osteoclasts
}

\author{
Takeru Kondo ${ }^{a, b}$, Keiichi Kanayama ${ }^{a, c}$, Hiroshi Egusa ${ }^{b}$, Ichiro Nishimura ${ }^{a, *}$ \\ a Weintraub Center for Reconstructive Biotechnology, UCLA School of Dentistry, Los Angeles, CA 90095-1668, USA \\ ${ }^{b}$ Division of Molecular and Regenerative Prosthodontics, Tohoku University Graduate School of Dentistry, Sendai 980-8575, Japan \\ ' Department of Periodontology, Division of Oral Infections and Health Science, Asahi University School of Dentistry, Gifu, Japan, 501-0296
}

\begin{abstract}
Purpose: Tooth extraction is a last resort treatment for resolving pathological complications of dentition induced by infection and injury. Although the extraction wound generally heals uneventfully, resulting in the formation of an edentulous residual ridge, some patients experience long-term and severe residual ridge reduction. The objective of this review was to provide a contemporary understanding of the molecular and cellular mechanisms that may potentially cause edentulous jawbone resorption.

Study selection: Clinical, in vivo, and in vitro studies related to the characterization of and cellular and molecular mechanisms leading to residual ridge resorption.

Results: The alveolar processes of the maxillary and mandibular bones uniquely juxtapose the gingival tissue. The gingival oral mucosa is an active barrier tissue that maintains homeostasis of the internal organs through its unique barrier immunity. Tooth extraction not only generates a bony socket but also injures oral barrier tissue. In response to wounding, the alveolar bone socket initiates regeneration and remodeling through coupled bone formation and osteoclastic resorption. Osteoclasts are also found on the external surface of the alveolar bone, interfacing the oral barrier tissue. Osteoclasts in the oral barrier region are not coupled with osteoblastic bone formation and often remain active long after the completion of wound healing, leading to a net decrease in the alveolar bone structure.

Conclusion: The novel concept of oral barrier osteoclasts may provide important clues for future clinical strategies to maintain residual ridges for successful prosthodontic and restorative therapies.
\end{abstract}

Keywords: Residual Ridge Resorption, Oral Barrier Tissue, Osteoclast, Tooth Extraction

Received 7 December 2021, Accepted 31 January 2022, Available online 21 February 2022

\section{Introduction}

Tooth extraction is a last resort treatment option that surgically removes the affected dentition as the source of oral microbial infection causing irreversible structural degradation of teeth by dental caries and exuberant inflammation of periodontal tissue by periodontitis. The latest U.S. National Health and Nutrition Examination Survey reported that $3.75 \%$ of adults aged 20 to 64 years and $27.27 \%$ of older adults over the age of 65 had total loss of teeth [1].

Tooth extraction creates an alveolar bone socket and gingival open wound, which normally undergoes uneventful healing, leading to the formation of a residual alveolar ridge. However, the volume of the residual ridge gradually decreases after a series of morphological changes, which have been described as residual ridge reduction $[2,3]$. Residual ridge reduction continues throughout life in some patients, leading to a large cumulative loss of jawbone structure that

DOI: https://doi.org/10.2186/jpr.JPR_D_21_00333

*Corresponding author: Ichiro Nishimura, Weintraub Center for Reconstructive Biotechnology, UCLA School of Dentistry.

E-mail address: inishimura@dentistry.ucla.edu

Copyright: @ 2022 Japan Prosthodontic Society. All rights reserved. significantly limits the quality of life. Therefore, it has been proposed that residual ridge reduction should be recognized as a pathological disease entity [4].

Tooth extraction can cause dimensional changes in the alveolar bone within the first six months, potentially limiting dental implant treatment. To maintain residual ridge morphology, various procedures have been postulated, such as socket or alveolar ridge preservation, with clinical success $[5,6]$. However, because the pathological mechanism of residual ridge resorption has not been fully established, current preservation methods may lack biological rationale or design principles.

There is an acute need to elucidate the mechanism of edentulous jawbone resorption to facilitate functional and esthetic dental restoration and craniofacial rehabilitation. The pathological mechanism has been examined from various perspectives, such as the patients' own anatomical structure [7-9], biomechanical contribution [10-16], and association with systemic diseases [17-22]. However, we still do not know how edentulous jawbone resorption continues even long after the tooth extraction wound is healed, and how some patients lose a large amount of jawbone structure. This review provides the current perspective on the pathology of residual ridge re- 

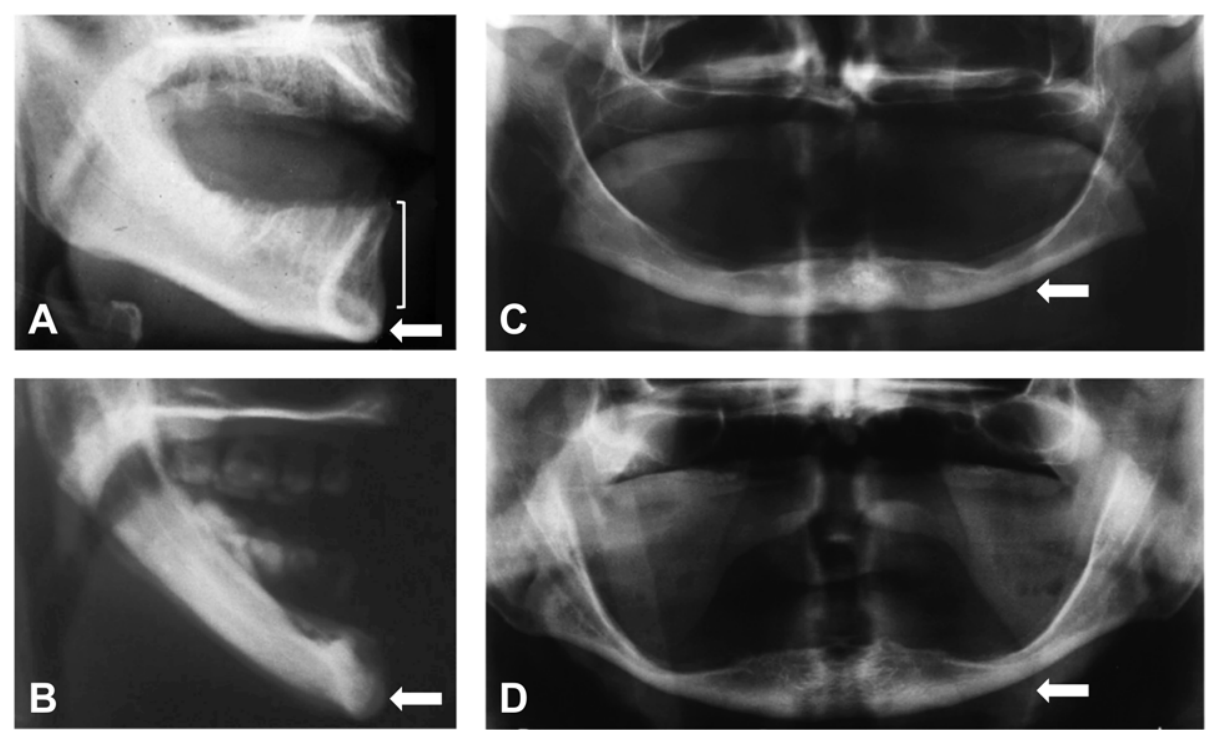

Fig. 1. Edentulous jawbone. A. Immediately after tooth extraction. Extraction sockets are visible in the alveolar process of the mandible (bracket). B. Long after tooth extraction of the same patient as A. The alveolar bone was largely lost while the mandibular body (arrow) is well maintained. C. D. Panoramic radiographs of edentulous patients that similarly exhibit the loss of the edentulous alveolar bone, while mandibular body (arrows) remained less affected.

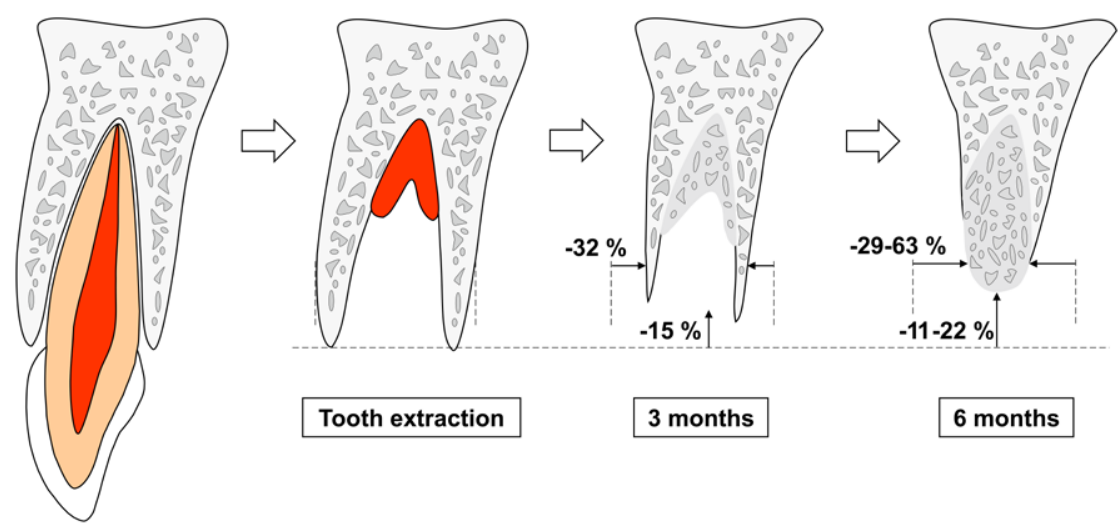

Fig. 2. Clinical reports repeatedly confirmed that the residual ridge formed after tooth extraction underwent size reduction of the width and the height over time. This is thought to be due to active osteoclastic bone resorption from the external surface of the alveolar process of the edentulous jawbone.

sorption and provides the biological rationale for a clinical means to reduce dental disability after tooth extraction.

\section{Clinical characterization of residual ridge reduction}

Residual ridge reduction following tooth extraction has been characterized using standardized lateral cephalographs (Fig. 1A, B) [7-10,13,14,16,21,23-29] and panoramic radiographs (Fig. 1C, D) $[20,30]$ to evaluate underlying jawbone structural changes. More recently, alveolar bone reduction has been characterized by cone beam computed tomography (CBCT), and the residual ridge contour has been examined by digital impression, possible due to technological progress [31-33].
After tooth extraction, the buccolingual width of the residual alveolar bone was reduced more than the height. The rate of height reduction, calculated as the percentage of vertical linear reduction over the distance between the bottom of the socket and the crest of alveolar bone before tooth extraction, was $15 \%$ and $11-22 \%$ at 3 and 6 months, respectively. The rate of buccolingual width reduction, calculated as the percentage of horizontal linear reduction over the distance between the buccal and lingual borders of the alveolar bone before tooth extraction, was $32 \%$ and $29-63 \%$ at 3 and 6 months, respectively [34]. However, crestal bone height change varied depending on the site $[34,35]$. These results from clinical observations suggest that the structural change in the edentulous jawbone is unidirectional and is primarily induced by resorption of the residual alveolar bone by osteoclasts (Fig. 2). 


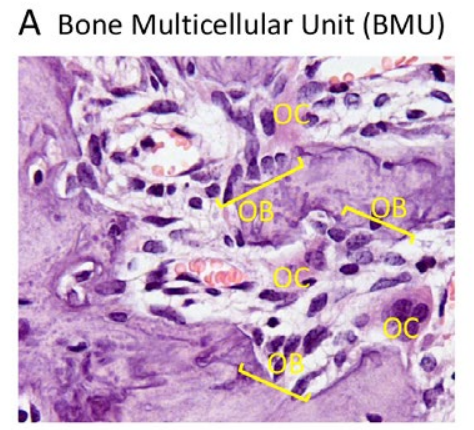

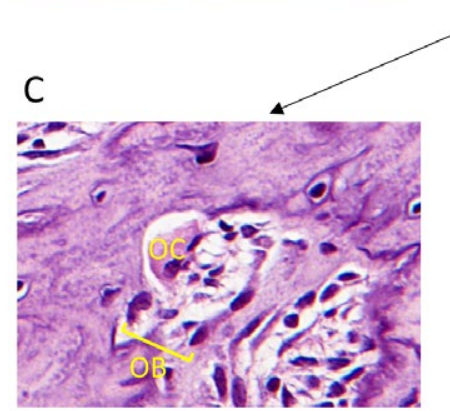

Extraction Socket

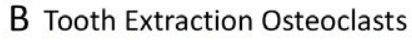 \\ B Tooth Extraction Osteoclasts}

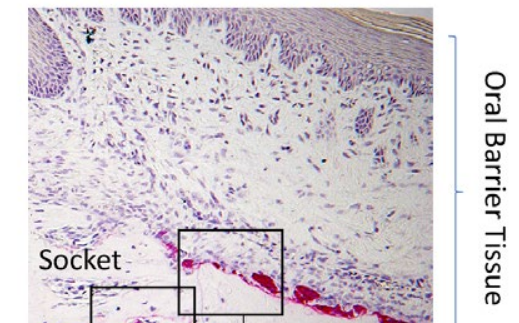

Fig. 3. A. Bone resorbing osteoclasts $(\mathrm{OC})$ in bone marrow (mouse mandible; HE staining) associate closely with bone-forming osteoblasts (OB), which together organize the bone multicellular unit (BMU). B. After tooth extraction, osteoclasts are abundantly observed on the external surface of the alveolar bone interfacing the oral barrier tissue and within the remodeling bone in the socket (mouse maxillary $1^{\text {st }}$ molar; TRAP staining). C. Extraction socket osteoclasts appeared to form BMU with osteoblasts (HE staining). D. Unlike bone marrow BMU, oral barrier osteoclasts do not associate with osteoblasts; however, they often juxtapose oral barrier inflammatory cells, likely lymphocytes (arrows) (HE staining).

\section{Osteoclasts and bone remodeling}

Osteoclasts are multinuclear, large cells capable of secreting an acidic milieu to dissolve bone minerals, and strong proteinases, such as cathepsin $\mathrm{K}$, to digest organic bone collagen extracellular matrices [36]. Unlike bone-forming osteoblasts of mesenchymal stem cell origin, osteoclasts are derived from monocytes/macrophages, myeloid immune cells, or osteoclast progenitor cells. Macrophage colony-stimulating factor (M-CSF) promotes the fusion of osteoclast progenitors [37]. Receptor activator of nuclear factor kappa-B ligand (RANKL) is also an essential factor for osteoclastogenesis and survival [38]. Extensive studies have demonstrated that osteoblasts are a cellular source of RANKL during bone remodeling [39-44]. More recently, osteocytes were found to be the primary cellular source of RANKL during physiological bone remodeling [45]. Osteoprotegerin (OPG), a decoy receptor of RANKL, can bind to RANKL and inhibit its activity, resulting in inhibition of osteoclastogenesis and bone resorption $[46,47]$. Therefore, the RANKL/OPG ratio is crucial for osteoclastogenesis [48].

Bone remodeling plays a critical role in the repair and replacement of damaged bone and involves osteoclastic bone resorption followed by osteoblastic bone formation. The balance between coupled bone resorption and formation maintains the net volume and structure of bone. It has been hypothesized that osteoclastic bone resorption releases embedded growth factors in the bone marrow to differentiate osteoblasts [49]. Osteoclasts and osteoblasts are closely associated with the transient structure of basic multicellular unit (BMU) (Fig. 3A). It is believed that coupled bone remodeling occurs within the BMU canopy [50]. However, the behavior of osteoclasts on the external surface of the alveolar bone socket appears to be distinctly different from that of bone remodeling osteoclasts and lacks coupled osteoblastic bone formation (Fig. 3B).

\section{Osteoclasts associate with oral barrier tissue}

Clinical observations have repeatedly shown the abnormal behavior of post-tooth extraction alveolar bone, which decreases in height and width over time (Fig. 1, 2, Table 1). It is well established that residual alveolar bone does not increase in size. However, the mechanism of residual ridge reduction is not well understood. The unique aspect of residual ridge resorption is aberrant osteoclastic activity at the bony margin of the socket and the external surface of the alveolar bone [51,52]. Aberrant osteoclastogenesis on the external alveolar bone surface is not a part of physiological bone remodeling, but may be regulated by the oral barrier tissue and function. We propose that osteoclasts associated with oral barrier tissue are primarily responsible for residual ridge resorption because oral barrier osteoclasts reside in the resorption pits on the external surface of the alveolar bone without coupled osteoblastic bone formation, resulting in the net loss of bone structure.

Tooth extraction not only creates defects in the alveolar bone but also causes trauma to the gingival tissue. The external alveolar bone surface closely interfaces with the gingiva or oral barrier tissue. Barrier tissues such as the skin, intestine, and gingiva/oral mucosa are equipped with a tissue-specific barrier immune system and protect internal tissue homeostasis from external physical, thermal, and microbial insults [53-55]. Disruptions of barrier tissue and cell membrane microbarriers release multiple signaling molecules, including 
Table 1. Clinical Reports of Residual Ridge Reduction

\begin{tabular}{|c|c|c|c|c|c|}
\hline Tissue & \multicolumn{2}{|l|}{ Site } & $\begin{array}{l}\text { Dimensional } \\
\text { change }\end{array}$ & Duration & Reference \\
\hline \multirow{10}{*}{$\begin{array}{l}\text { Alveolar } \\
\text { bone }\end{array}$} & \multirow{6}{*}{ Height } & Mid-buccal & $-1.24 \mathrm{~mm}$ & 6 months & [34] \\
\hline & & Mid-lingual & $-0.5 \mathrm{~mm}$ & 6 months & [129] \\
\hline & & Mesial & $-0.84 \mathrm{~mm}$ & 6 months & \multirow{2}{*}[34]{} \\
\hline & & Distal & $-0.8 \mathrm{~mm}$ & 6 months & \\
\hline & & \multirow{2}{*}{ All } & $-15.7 \%$ & 3 months & [130] \\
\hline & & & $-11-22 \%$ & 6 months & [34] \\
\hline & \multirow{4}{*}{ Width } & \multirow{4}{*}{ All } & $-3.2 \mathrm{~mm}$ & 3 months & [131] \\
\hline & & & $-32 \%$ & 3 months & \multirow{3}{*}{ [34] } \\
\hline & & & $-3.79 \mathrm{~mm}$ & 6 months & \\
\hline & & & $-29-63 \%$ & 6 months & \\
\hline \multirow{11}{*}{ Soft tissue } & \multirow{6}{*}{ Height } & \multirow{2}{*}{ Buccal } & $-0.1 \mathrm{~mm}$ & 3 months & \multirow{4}{*}{ [132] } \\
\hline & & & $+0.4 \mathrm{~mm}$ & 12 months & \\
\hline & & \multirow{2}{*}{ Lingual } & $-0.8 \mathrm{~mm}$ & 3 months & \\
\hline & & & $-0.8 \mathrm{~mm}$ & 12 months & \\
\hline & & \multirow{2}{*}{ All } & $-0.1 \mathrm{~mm}$ & 3 months & \multirow{2}{*}{ [133] } \\
\hline & & & $-0.5 \mathrm{~mm}$ & 12 months & \\
\hline & \multirow{2}{*}{ Width } & \multirow{2}{*}{ All } & $-3.8 \mathrm{~mm}$ & 3 months & \multirow{2}{*}{ [132] } \\
\hline & & & $-6.1 \mathrm{~mm}$ & 12 months & \\
\hline & \multirow{3}{*}{ Thickness } & Buccal & $-0.4 \mathrm{~mm}$ & 6 months & \multirow{2}{*}{ [129] } \\
\hline & & Lingual & $-0.5 \mathrm{~mm}$ & 6 months & \\
\hline & & All & $-0.1-+4.8 \mathrm{~mm}$ & 2 months & [31] \\
\hline
\end{tabular}

damage-associated molecular patterns (DAMPs) and pathogenassociated molecular patterns (PAMPs). These molecular danger signals are sensed by inflammatory cells through pattern recognition receptors, such as toll-like receptors. The resultant inflammatory response in the oral barrier tissue is designed to clear the molecular danger and induce tissue repair mechanisms of wound healing $[56,57]$.

Although the precise mechanism has not yet been elucidated, residual ridge osteoclasts appear to be influenced by oral barrier immunity. The close proximity of oral barrier tissue and, potentially, its immune cells to osteoclasts on the external surface of the alveolar bone (Fig. 3D) prompted us to investigate the role of oral barrier lymphocytes, which may initiate the recruitment of osteoclasts, as shown in the tooth extraction model [58-60]. In wild-type mice, osteoclasts were observed inside the extraction socket and on the external surface of the alveolar bone after tooth extraction (Fig. 4A). When the same tooth extraction was performed in Rag2-/- mice, genetically lacking functional $\mathrm{T}$ and $\mathrm{B}$ lymphocytes, normal osteoclastogenesis was induced in remodeling the bone inside the socket. However, no osteoclasts were observed on the external surface of the alveolar bone interfacing the oral barrier tissue (Fig. 4B) [60]. Tooth extraction from Rag2-/- mice demonstrated a total lack of osteoclasts interfacing oral barrier tissue, suggesting that oral barrier osteoclasts responsible for residual ridge resorption require an interaction with lymphocytes. To further examine the role of lymphocytes, Rag2-/mice were repopulated with human peripheral blood $\mathrm{CD}^{+} \mathrm{T}$ cells ( $\mathrm{hCD} 3^{+} \mathrm{T}$ cells) by intraperitoneal injection. $\mathrm{hCD}^{+} \mathrm{T}$ cell repopulation resulted in the presence of oral barrier osteoclasts (Kanayama and Nishimura, unpublished, Fig. 4C, 4D). Thus, we propose that $T$ cells in oral barrier tissue are responsible for the development of oral barrier osteoclast.
Similar to the long bones, the body of the jawbone is covered by the periosteum (Fig. 4C), which provides the blood supply and contains active cells capable of bone formation [61]. In adult bones, the periosteal reaction or abnormal bone formation can be found on the external bone surface associated with diseases such as osteomyelitis and bone tumors [62]. While rare, the jawbone can also develop a periosteal reaction [63,64]. Medication-related osteonecrosis of the jaw has been reported to develop the periosteal reaction at the jawbone body covered by the periosteum $[65,66]$ (Fig. 4E). It must be noted that periosteal reaction has never been associated with alveolar bone. This observation further highlights the unique characteristics of alveolar bone interfacing the oral barrier tissue.

\section{Cellular source of RANKL in the oral barrier tissue}

Oral barrier tissue is composed of oral epithelial cells [67], distinct gingival and periodontal ligament fibroblasts [68], and oral immune cells [55]. In addition, osteoblastic progenitor cells are primarily localized in the periodontal ligament space [69]. Tsukasaki (2021) investigated the cellular source of RANKL in a mouse ligatureinduced periodontitis model [70]. RANKL-encoding Tnfsf11-floxed mice were crossed with mice carrying Mb1-Cre (targeting B-cells), CD4-Cre (targeting T-cells), Scx-Cre (targeting fibroblasts), and Sp7-Cre (targeting osteoblasts). Ligature-induced bone resorption and osteoclastogenesis were significantly decreased in Tnfsf11. CD4-Cre, Tnfsf11.Scx-Cre, and Tnfsf11.Sp7-Cre mice, suggesting that the cellular source of RANKL was T cells, fibroblasts, and osteoblasts. Recently, Yang et al. (2018) induced a RANKL knockout mutation specific to type I collagen-expressing cells in Col1a1.CreER.RANKL ${ }^{\mathrm{fl} / \mathrm{fl}}$ mice and found that periodontal ligament osteoclasts significantly decreased during orthodontic tooth movement [71]. Since Col1a1. CreER.ROSA-positive cells were localized throughout the periodontal ligament space, oral fibroblasts were considered the cellular source of RANKL in response to orthodontic tooth movement.

RANKL is present in the gingival crevicular fluid, and thus gingival sulcus-lining oral epithelial cells are postulated to express RANKL [72]. RANKL is selectively expressed in the intestinal mucosa by subepithelial stromal cells (fibroblasts), which play an important role in organizing intestinal Peyers patches and other organized mucosal lymphoid tissues [73]. The function of gingival sulcus epithelial RANKL, including its role in osteoclastogenesis, has not yet been elucidated. After tooth extraction, the periodontal ligament initially provides bone-regenerating cells in the extraction socket and progressively disintegrates. The resultant edentulous oral mucosa has been associated with chronic inflammation and changes in connective tissue structure particularly with the use of removable dentures $[74,75]$. In this review, we discuss the molecular and cellular mechanisms of residual ridge resorption, focusing on oral barrier immune cells and fibroblasts.

\section{Oral barrier Th17 cells respond to mechanical stimulation}

The immune system of the oral barrier tissue can adapt well to constant external stimuli and plays a crucial role in immune surveillance while tolerating commensal microbes and harmless antigens without excessive inflammation [76]. Tissue injury results in the synthesis of local cytokines and guides naïve helper T (Th) cells to differentiate into Th1, Th2, Th17, and regulatory T (Treg) cell subunits [77]. 

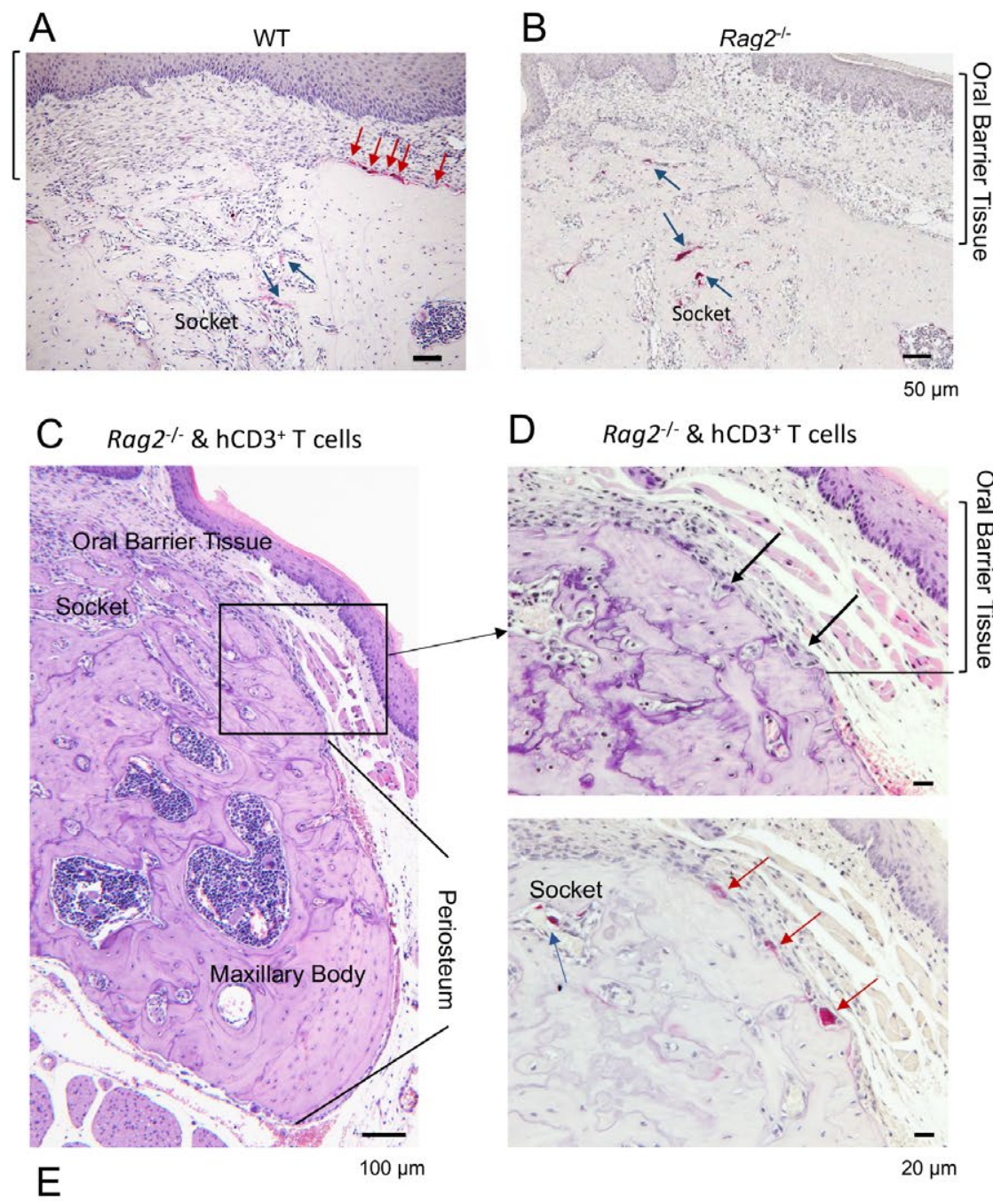

D $\quad \operatorname{Rag} 2 \%$ \& $\mathrm{hCD}^{+} \mathrm{T}$ cells
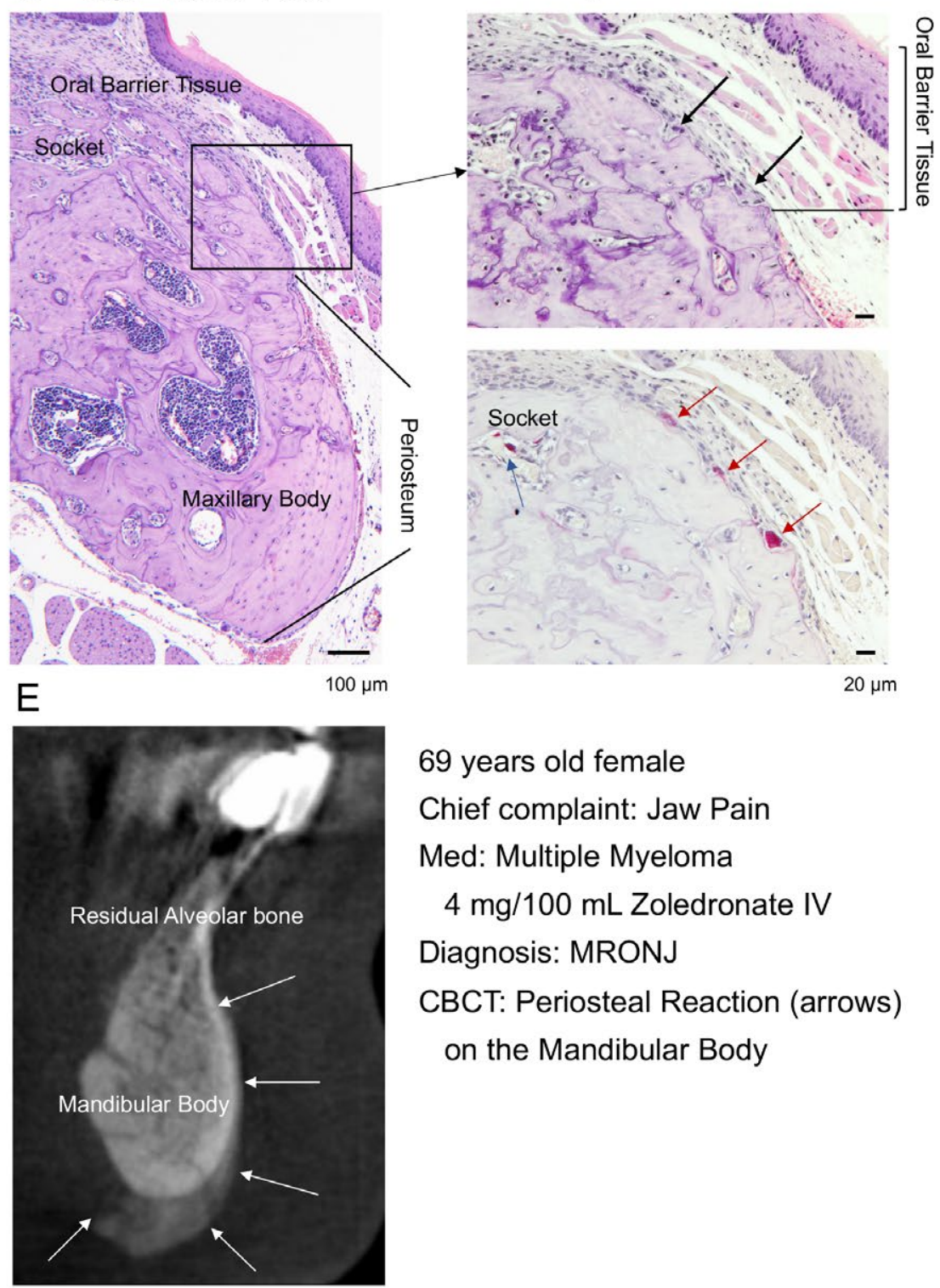

69 years old female Chief complaint: Jaw Pain

Med: Multiple Myeloma

$4 \mathrm{mg} / 100 \mathrm{~mL}$ Zoledronate IV Diagnosis: MRONJ

CBCT: Periosteal Reaction (arrows) on the Mandibular Body

Fig. 4. Unique behaviors of the alveolar bone interfacing with oral barrier tissue. A. After maxillary first molar extraction of wild type (WT) mice, the bony socket was filled with active bone regeneration and remodeling, including osteoclasts (blue arrows). A separate cluster of oral barrier osteoclasts (red arrows) was observed on the external surface of the alveolar bone (TRAP staining). B. The maxillary molar extraction of Rag $2^{-/}$mice lacking functional lymphocytes induced bony socket bone regeneration and remodeling with osteoclasts; however, oral barrier osteoclasts were not observed. Lymphocytes are required for the development of oral barrier osteoclasts (TRAP staining). C. Rag2 ${ }^{--}$mice were repopulated with human peripheral blood $\mathrm{CD}^{+} \mathrm{T}$ cells $\left(\mathrm{hCD} 3^{+} \mathrm{T}\right.$ cells). Bone resorption lacunae were observed in the alveolar bone interfacing with oral barrier tissue (the enclosed area; also black arrows in Fig. 3D) (HE staining). The maxillary body was covered by the periosteum (Kanayama and Nishimura, Unpublished). D. Magnification images of the square in Fig. 3C (upper panel: HE staining, lower panel: TRAP staining). While the bone remodeling with osteoclasts (blue arrow) in the extraction socket was maintained, Rag2-- mice repopulated with $\mathrm{hCD}^{+} \mathrm{T}$ cells showed a new sign of bone resorption on the external surface of the alveolar bone, with TRAP ${ }^{+}$osteoclasts (red arrows) (Kanayama and Nishimura, Unpublished). E. Mandibular CBCT image of an MRONJ patient depicted periosteal reaction or abnormal bone formation in the periosteum covering the mandibular body (Courtesy of Dr. Sil Park). 
Interactions between T cells and osteoclasts have been reported in pathological osteolytic diseases and have been described as osteoimmunology [78]. Activated T cells can regulate osteoclastogenesis by expressing RANKL and other cytokines that have either stimulatory or inhibitory effects $[79,80]$. RANKL secreted by activated $T$ cells explains the mechanism of disease-induced bone resorption in autoimmune diseases [81], cancers [82], and peri-implant osteolysis [83]. Therefore, osteoclastic alveolar bone resorption during tooth extraction wound healing may be caused by a similar mechanism involving an injury-induced oral barrier immune reaction. However, the long-term presence of oral barrier osteoclasts needs to be addressed.

Among Th cell subunits, Th17 cells are involved in promoting osteoclastogenesis. Th17 cells are characterized by the expression of IL-17A, IL-17F, IL-21, and IL-22 [84,85]. In a mouse model of rheumatoid arthritis, IL-17 expressed by Th17 cells promoted osteoclastogenesis by inducing RANKL expression in synovial fibroblasts and mesenchymal cells. In addition, IL-17 stimulated innate immune cells to express inflammatory cytokines, such as TNF- $\alpha$, IL-1 $\beta$, and IL- 6 , which enhance the expression of RANKL in mesenchymal cells and activate RANK signaling in osteoclasts [86]. It has also been reported that Th17 cells directly expressed RANKL [86]. Thus, Th17 cells are closely associated with bone resorption.

Th17 cells of the intestinal and skin barrier tissues are activated by commensal microbial interactions $[87,88]$. Unlike these barrier tissues, oral barrier Th17 cells do not respond to oral commensal microbes [89]. When mice were fed soft food, Th17 cells were not detected in the oral barrier tissue. In contrast, hard pellet food or other mechanical stimuli to the palatal gingival tissue significantly increased the number of Th17 cells in the oral barrier [89]. These results indicate that Th17 cell development in oral barrier tissue requires crucial molecular signals from mechanical stimuli. It may be proposed that oral barrier Th17 cell development by excessive mechanical stimulation may cause oral barrier osteoclastogenesis affecting the external surface of the alveolar bone.

\section{Prostaglandin E2 synthesis in oral barrier fibroblasts by mechanical stimulation}

Orthodontic tooth movement exerts mechanical stimuli on the periodontal ligament space and induces osteoclastic bone resorption. Fibroblasts are the major cell type occurring in the periodontal ligament, which attaches teeth to the alveolar bone [90,91]. During orthodontic tooth movement, the loading pressure induced RANKL expression in fibroblasts, which were localized in the compressed site, as well as osteocytes and osteoblasts [92-95]. Prostaglandin E2 (PGE2), which is known to induce inflammation [96] and bone resorption [97], was synthesized by fibroblasts in response to mechanical stress [98-101]. Therefore, PGE2 is a key factor in osteoclastogenesis during tooth movement. When mechanical force was applied to periodontal ligament fibroblasts, PGE2 was produced via the cyclooxygenase pathway [102]. Compressive force significantly increased the RANKL/OPG ratio of periodontal ligament fibroblasts at both the gene and protein levels, with increased secretion of PGE2 [103]. Exogenous PGE2 induced RANKL expression in fibroblasts [98] and stimulated fibroblasts to produce IL-6 and IL-8 [104] which activates $\mathrm{M}-\mathrm{CSF}$ and RANKL production, resulting in bone resorption.

An increase in PGE2 levels of 50\% and $90 \%$ at 1 and 14 days of orthodontic treatment, respectively, at compression sites in orthodontically treated cats has been reported [105]. Yamasaki et al. showed that indomethacin, a specific inhibitor of PG synthetase, suppressed the number of osteoclasts and alveolar bone resorption during experimental tooth movement [97]. Nishimura et al. examined the role of PGE2 in edentulous jawbone resorption in rats and found that indomethacin treatment decreased long-term residual alveolar bone resorption, which was, in part, reversed by continuous infusion of PGE2 by an osmotic pump [106]. It has been proposed that mechanical stress to the oral barrier tissue may be sensed by fibroblasts and enhances osteoclastogenesis by increased secretion of PGE2, as well as increased RANKL/OPG ratio and M-CSF production. Indeed, Akashi et al. recently demonstrated that conditioned media obtained from human gingival fibroblasts cultured under cyclic pressure promoted osteoclastogenesis [107].

\section{Excessive wearing of removable dentures increases the residual ridge resorption}

Over seven decades, numerous clinical investigations have addressed local and systemic factors linked to severe residual ridge reduction. In 1960, Campbell et al. reported that the denture-wearer group had shorter and narrower residual ridges than the nondenture-wearer group in a cross-sectional study of institutionalized edentulous patients [108]. Atwood and Coy (1971) similarly addressed the time of denture wearing in edentulous subjects and reported an insignificant but strong trend for longer denture wearers to have a more severe residual ridge reduction [7]. A series of prospective studies monitored patients with complete maxillary edentulism opposing partial edentulism in the posterior segments of the mandible $[16,109]$. Mandibular posterior residual ridge resorption was documented in subjects wearing maxillary complete dentures and mandibular distal extension removable partial dentures (RPD), whereas the morphology of the mandibular posterior ridge remained relatively unchanged in subjects who did not wear RPD. More recently, Alsaggaf and Fenlon (2020) reported that excessive denture wearing for more than five years significantly increased residual ridge resorption compared to non-denture-wearing edentulous patients [110]. Furthermore, Pham et al. reported in a systematic review that two implant-assisted overdenture treatments increased the rate of posterior residual ridge resorption compared to four implant-supported overdenture treatments, indicating that increasing mechanical pressure on the posterior edentulous gingiva might promote residual ridge resorption [111].

Denture stomatitis is described as oral mucosal inflammation within the area covered by the denture, primarily caused by poor denture hygiene as well as continual and nighttime wearing of removable dentures [112]. Based on these empirical observations, patients are advised to remove dentures and facilitate daily rest of the residual ridge. Although the exact mechanism of residual ridge resorption associated with excessive denture wearing has not been fully elucidated, we hypothesize that the disproportionate force applied from the denture base may cause the activation of underlining oral barrier immunity, leading to edentulous jawbone loss (Fig. 5).

\section{Oral barrier connective tissue contraction as a mechanism of residual ridge resorption}

Compared with skin wounds, oral wounds are associated with less inflammatory cell infiltration [113] and less proinflammatory cytokine expression [114]. Oral fibroblasts isolated from the tooth extraction site of rats caused a much faster contraction of the floating 


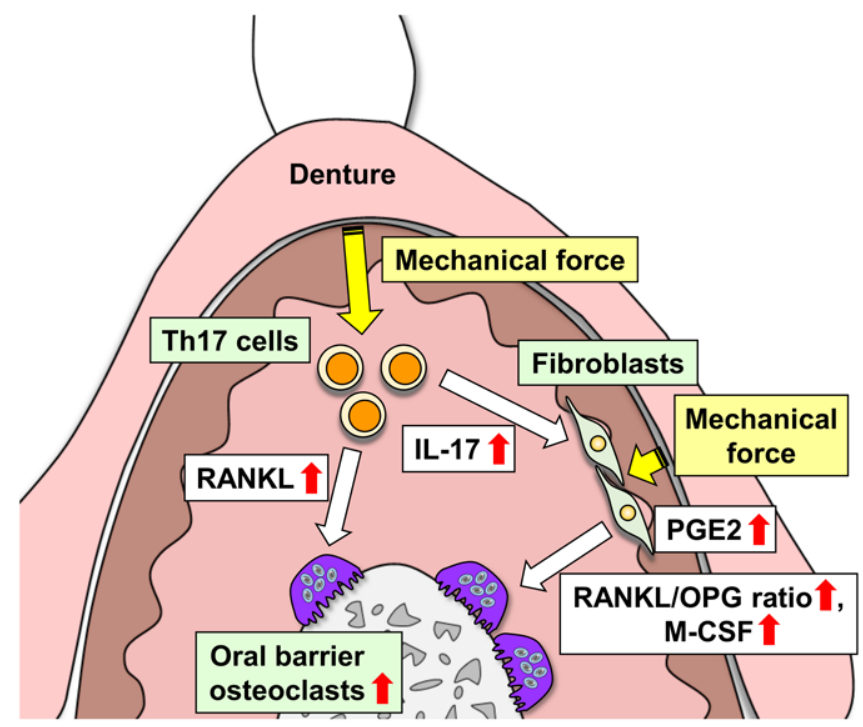

Fig. 5. Proposed molecular and cellular mechanism of denture-induced residual ridge resorption involving oral barrier osteoclasts.

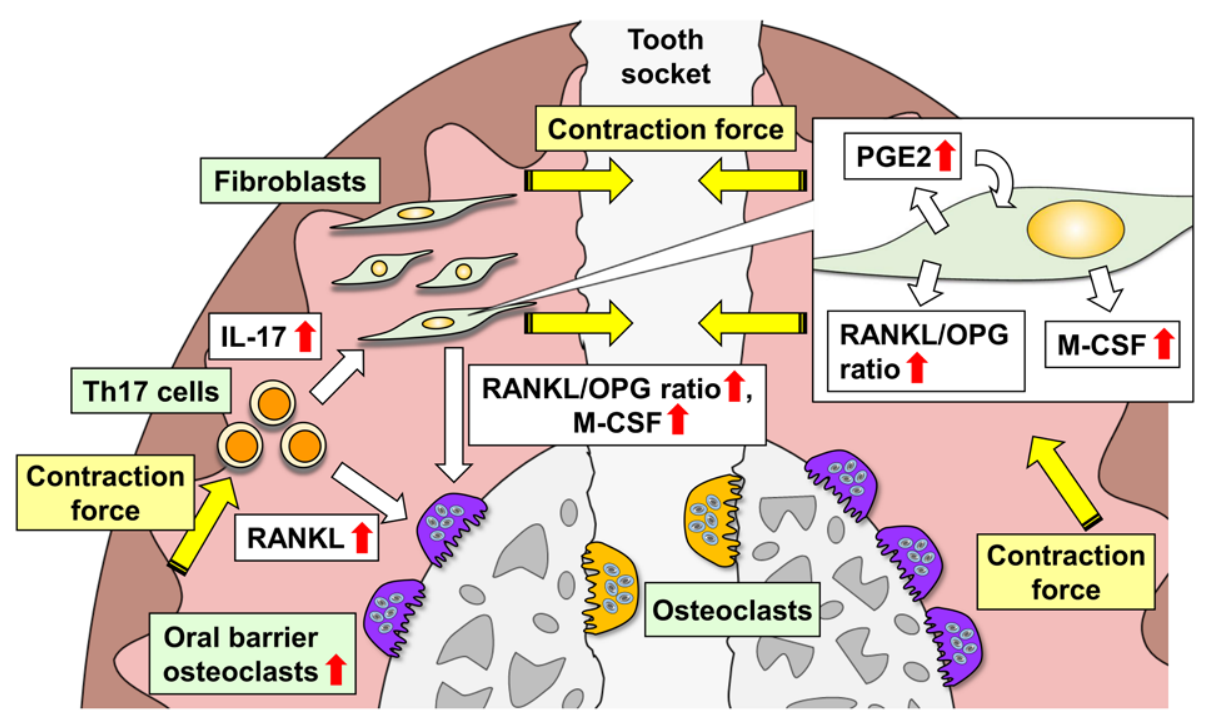

Fig. 6. Proposed mechanism of post-tooth extraction and long-term residual ridge resorption influenced by oral barrier connective tissue contraction.

collagen gel in vitro than skin fibroblasts [115,116]. Accelerated floating collagen gel contraction by oral fibroblasts is a consistent and reproducible observation [117-119]. Fibroblasts migrate through the wound collagen connective tissue lattice and contribute to wound contraction by generating tensile strength. Therefore, the intrinsic force within the oral barrier tissue may result from accelerated oral wound closure and contraction, even long after tooth extraction.

The edentulous maxilla of female patients with osteoporosis exhibit a characteristically highly resorbed morphology and are covered by a thin oral mucosa [20], whereas the edentulous mandible tends to be a knife-edge ridge covered by a thick bundle of oral mucosa $[21,120]$. In a rare pathological condition, oral submucosal fibrosis, was reported to be associated with highly resorbed edentulous ridges [121]. The pattern of edentulous jawbone resorption may be closely associated with the morphology and thickness of the overlying oral barrier tissue. It is conceivable that the intrinsic mechanical force induced by oral barrier tissue contraction may stimulate the osteoclastogenic oral barrier tissue environment (Fig. 6).

\section{Conclusion and future perspectives}

This review discusses the biological and pathological roles of oral barrier tissue, potentially influencing the closely associated alveolar bone of the edentulous jaw. We propose that osteoclasts responsible for residual ridge resorption should be considered oral barrier cells and are not coupled with subsequent osteoblastic bone formation. Given their monocyte/macrophage myeloid immune cell origin, oral barrier osteoclasts may also have immune regulatory characteristics $[122,123]$. Continuous induction of oral barrier osteoclasts is a 
primary concern for the prevention of residual ridge resorption. Mechanical stimuli to oral barrier tissue may play a pathological role. We propose a novel biological rationale for socket preservation by preventing or reducing intrinsic oral barrier tissue contraction and the resultant tensile strength. Clinical studies of the edentulous jawbone demonstrated a wide variation among our patients, which masked the effect of postulated causal factors contributing to edentulous jawbone resorption. Increasing investigations into genetic polymorphisms [124-128] may shed light on the mechanisms of individual variations in the future.

\section{Acknowledgements}

Research support related to this review was in part from NIH/ NIDCR R01 DE022552 (IN) and JSPS Research Fellowship for Young Scientists (19J117670) (TK).

\section{Conflicts of interest}

IN reports his role as a consultant of FUJIFILM Corp and BioVinc LLC. All other authors declare no competing interests.

\section{References}

[1] Schwendicke F, Dorfer CE, Schlattmann P, Foster Page L, Thomson WM, Paris S. Socioeconomic inequality and caries: a systematic review and meta-analysis. J Dent Res 2015;94(1):10-8. https://doi.org/10.1177/ 0022034514557546, PMID:25394849

[2] Tallgren A. Changes in adult face height due to aging, wear and loss of teeth and prosthetic treatment. Acta Odontol Scand 1957;15(supp. 24):7122.

[3] Atwood DA. A cephalometric study of the clinical rest position of the mandible: Part II. The variability of the rate of bone loss following the removal of occlusal contacts. J Prosthet Dent 1957;7(4):544-52. https://doi. org/10.1016/0022-3913(57)90062-8

[4] Atwood DA. Reduction of residual ridges: a major oral disease entity. J Prosthet Dent 1971;26(3):266-79. https://doi.org/10.1016/0022-3913(71)90069-2, PMID:4934947

[5] Juodzbalys G, Stumbras A, Goyushov S, Duruel O, Tozum TF. Morphological Classification of Extraction Sockets and Clinical Decision Tree for Socket Preservation/Augmentation after Tooth Extraction: a Systematic Review. J Oral Maxillofac Res 2019;10(3):e3. https://doi.org/10.5037/jomr.2019.10303, PMID:31620265

[6] Avila-Ortiz G, Elangovan S, Kramer KW, Blanchette D, Dawson DV. Effect of alveolar ridge preservation after tooth extraction: a systematic review and meta-analysis. J Dent Res 2014;93(10):950-8. https://doi.org/ 10.1177/0022034514541127, PMID:24966231

[7] Atwood DA, Coy WA. Clinical, cephalometric, and densitometric study of reduction of residual ridges. J Prosthet Dent 1971;26(3):280-95. https://doi. org/10.1016/0022-3913(71)90070-9, PMID:5284182

[8] Winter CM, Woelfel JB, Igarashi T. Five-year changes in the edentulous mandible as determined on oblique cephalometric radiographs. J Dent Res 1974;53(6):1455-67. https://doi.org/10.1177/00220345740530062801, PMID:4610022

[9] Tallgren A. Alveolar bone loss in denture wearers as related to facial morphology. Acta Odontol Scand 1970;28(2):251-70. https://doi.org/ 10.3109/00016357009032033, PMID:5268150

[10] Wictorin L. Bone Resorption in Cases with Complete Upper Denture. A Quantitative Roentgenographic-Photogrammetric Study. Acta Radiol Diagn (Stockh) 1964:SUPPL 228:1-97. PMID:14277172

[11] Johnson K. A three-year study of the dimensional changes occurring in the maxilla following immediate denture treatment. Aust Dent J 1967;12(2): 152-9. https://doi.org/10.1111/j.1834-7819.1967.tb02191.x, PMID:5229240

[12] Johnson K. A study of the dimensional changes occurring in the maxilla following open face immediate denture treatment. Aust Dent $J$ 1977;22(6):451-4. https://doi.org/10.1111/j.1834-7819.1977.tb05149.x, PMID: 274105
[13] Carlsson GE, Thilander H, Hedegard B. Histologic changes in the upper alveolar process after extractions with or without insertion of an immediate full denture. Acta Odontol Scand 1967;25(1):21-43. https://doi. org/10.3109/00016356709072521, PMID:5233857

[14] Carlsson GE, Bergman B, Hedegard B. Changes in contour of the maxillary alveolar process under immediate dentures. A longitudinal clinical and $\mathrm{x}$-ray cephalometric study covering 5 years. Acta Odontol Scand 1967;25(1):4575. https://doi.org/10.3109/00016356709072522, PMID:5233859

[15] Carlsson GE, Persson G. Morphologic changes of the mandible after extraction and wearing of dentures. A longitudinal, clinical, and $x$-ray cephalometric study covering 5 years. Odontol Revy 1967;18(1):27-54. PMID: 5227389

[16] Carlsson GE, Ragnarson N, Astrand P. Changes in height of the alveolar process in edentulous segments. A longitudinal clinical and radiographic study of full upper denture cases with residual lower anteriors. Odontol Tidskr 1967;75(3):193-208. PMID:5231586

[17] Mercier $P$, Inoue $S$. Bone density and serum minerals in cases of residual alveolar ridge atrophy. J Prosthet Dent 1981;46(3):250-5. https://doi.org/ 10.1016/0022-3913(81)90209-2, PMID:6943334

[18] Kribbs PJ, Smith DE, Chesnut CH, 3rd. Oral findings in osteoporosis. Part II: Relationship between residual ridge and alveolar bone resorption and generalized skeletal osteopenia. J Prosthet Dent 1983;50(5):719-24. https:// doi.org/10.1016/0022-3913(83)90215-9, PMID:6358473

[19] Ortman LF, Hausmann E, Dunford RG. Skeletal osteopenia and residual ridge resorption. J Prosthet Dent 1989;61(3):321-5. https://doi.org/10.1016/ 0022-3913(89)90137-6, PMID:2784169

[20] von Wowern N, Kollerup G. Symptomatic osteoporosis: a risk factor for residual ridge reduction of the jaws. J Prosthet Dent 1992;67(5):656-60. https://doi.org/10.1016/0022-3913(92)90165-7, PMID:1527750

[21] Nishimura I, Hosokawa R, Atwood DA. The knife-edge tendency in mandibular residual ridges in women. J Prosthet Dent 1992;67(6):820-6. https:// doi.org/10.1016/0022-3913(92)90592-x, PMID:1403869

[22] Nishimura I, Hosokawa R, Kaplan ML, Atwood DA. Animal model for evaluating the effect of systemic estrogen deficiency on residual ridge resorption. J Prosthet Dent 1995;73(3):304-10. https://doi.org/10.1016/ s0022-3913(05)80210-0, PMID:7760282

[23] DA A. Some clinical factors related to rate of resorption of residual idges. J Prosthet Dent 1962;12:441-50. https://doi.org/10.1067/mpr.2001.117609, PMID:11514795

[24] Carlsson GE, Oberg T, Bergman F, Fajers CM. Morphological changes in the mandibular joint disk in temporomandibular joint pain dysfunction syndrome. Acta Odontol Scand 1967;25(2):163-81. https://doi.org/ 10.3109/00016356709028745, PMID:5233923

[25] Tallgren A. The effect of denture wearing on facial morphology. A 7-year longitudinal study. Acta Odontol Scand 1967;25(5):563-92. https://doi.org/ 10.3109/00016356709028754, PMID:5247241

[26] Hickey JC, Henderson D, Straus R. Patient response to variations in denture technique. I. Design of a study. J Prosthet Dent 1969;22(2):158-70. https:// doi.org/10.1016/0022-3913(69)90243-1, PMID:4893688

[27] Tallgren A. The continuing reduction of the residual alveolar ridges in complete denture wearers: a mixed-longitudinal study covering 25 years. J Prosthet Dent 1972;27(2):120-32. https://doi.org/10.1016/0022-3913(72) 90188-6, PMID:4500507

[28] Woelfel JB, Winter CM, Igarashi T. Five-year cephalometric study of mandibular ridge resorption with different posterior occlusal forms. Part I. Denture construction and initial comparison.JProsthet Dent 1976;36(6):60223. https://doi.org/10.1016/0022-3913(76)90025-1, PMID:792430

[29] Steen WH. Errors in oblique cephalometric radiographic projections of the edentulous mandible. Part I: Geometric errors. J Prosthet Dent 1984;51(3):411-8. https://doi.org/10.1016/0022-3913(84)90233-6, PMID: 6584614

[30] Wical KE, Brussee P. Effects of a calcium and vitamin D supplement on alveolar ridge resorption in immediate denture patients. J Prosthet Dent 1979;41(1):4-11.https://doi.org/10.1016/0022-3913(79)90347-0,PMID:364037

[31] Chappuis V, Engel O, Shahim K, Reyes M, Katsaros C, Buser D. Soft Tissue Alterations in Esthetic Postextraction Sites: A 3-Dimensional Analysis. J Dent Res 2015;94(9 Suppl):187S-93S. https://doi.org/10.1177/0022034515592869, PMID:26130259

[32] Suenaga $H$, Yokoyama $M$, Yamaguchi K, Sasaki K. Time course of bone metabolism at the residual ridge beneath dentures observed using (1)(8)Ffluoride positron emission computerized-tomography/computed tomography (PET/CT). Ann Nucl Med 2012;26(10):817-22. https://doi.org/10.1007/ s12149-012-0648-6, PMID:22903818 
[33] Dekker H, Schulten E, Ten Bruggenkate CM, Bloemena E, van Ruijven L, Bravenboer N. Resorption of the mandibular residual ridge: A micro-CT and histomorphometrical analysis. Gerodontology 2018. https://doi.org/ 10.1111/ger.12343, PMID:29781536

[34] Tan WL, Wong TL, Wong MC, Lang NP. A systematic review of postextractional alveolar hard and soft tissue dimensional changes in humans. Clin Oral Implants Res 2012;23 Suppl 5:1-21. https://doi.org/10.1111/j.16000501.2011.02375.x, PMID:22211303

[35] Kerr EN, Mealey BL, Noujeim ME, Lasho DJ, Nummikoski PV, Mellonig JT. The effect of ultrasound on bone dimensional changes following extraction: a pilot study. J Periodontol 2008;79(2):283-90. https://doi.org/10.1902/ jop.2008.070289, PMID:18251642

[36] Teitelbaum SL. Osteoclasts: what do they do and how do they do it? Am J Pathol 2007;170(2):427-35. https://doi.org/10.2353/ajpath.2007.060834, PMID:17255310

[37] Yoshida H, Hayashi S, Kunisada T, Ogawa M, Nishikawa S, Okamura H, et al. The murine mutation osteopetrosis is in the coding region of the macrophage colony stimulating factor gene. Nature 1990;345(6274):442-4. https://doi.org/10.1038/345442a0, PMID:2188141

[38] Kong YY, Yoshida H, Sarosi I, Tan HL, Timms E, Capparelli C, et al. OPGL is a key regulator of osteoclastogenesis, lymphocyte development and lymph-node organogenesis. Nature 1999;397(6717):315-23. https://doi. org/10.1038/16852, PMID:9950424

[39] Matsuo K, Irie N. Osteoclast-osteoblast communication. Arch Biochem Biophys 2008;473(2):201-9. https://doi.org/10.1016/j.abb.2008.03.027, PMID:18406338

[40] Tamma R, Zallone A. Osteoblast and osteoclast crosstalks: from OAF to Ephrin. Inflamm Allergy Drug Targets 2012;11(3):196-200. https://doi. org/10.2174/187152812800392670, PMID:22280242

[41] Chen X, Wang Z, Duan N, Zhu G, Schwarz EM, Xie C. Osteoblast-osteoclast interactions. Connect Tissue Res 2018;59(2):99-107. https://doi.org/10.1080/ 03008207.2017.1290085, PMID:28324674

[42] Rho J, Altmann CR, Socci ND, Merkov L, Kim N, So H, et al. Gene expression profiling of osteoclast differentiation by combined suppression subtractive hybridization (SSH) and CDNA microarray analysis. DNA Cell Biol 2002;21(8):541-9. https://doi.org/10.1089/104454902320308915, PMID:12215257

[43] Woo KM, Kim HM, Ko JS. Macrophage colony-stimulating factor promotes the survival of osteoclast precursors by up-regulating Bcl-X(L). Exp Mol Med 2002;34(5):340-6. https://doi.org/10.1038/emm.2002.48, PMID: 12526097

[44] Kearns AE, Khosla S, Kostenuik PJ. Receptor activator of nuclear factor kappaB ligand and osteoprotegerin regulation of bone remodeling in health and disease. Endocr Rev 2008;29(2):155-92. https://doi.org/10.1210/ er.2007-0014, PMID:18057140

[45] Nakashima T, Hayashi M, Fukunaga T, Kurata K, Oh-Hora M, Feng JQ, et al. Evidence for osteocyte regulation of bone homeostasis through RANKL expression. Nat Med 2011;17(10):1231-4. https://doi.org/10.1038/nm.2452, PMID:21909105

[46] Schneeweis LA, Willard D, Milla ME. Functional dissection of osteoprotegerin and its interaction with receptor activator of NF-kappaB ligand. J Biol Chem 2005;280(50):41155-64. https://doi.org/10.1074/jbc.m506366200, PMID:16215261

[47] Hofbauer LC, Schoppet M. Clinical implications of the osteoprotegerin/ RANKL/RANK system for bone and vascular diseases.JAMA 2004;292(4):4905. https://doi.org/10.1001/jama.292.4.490, PMID:15280347

[48] Boyce BF, Xing L. Functions of RANKL/RANK/OPG in bone modeling and remodeling. Arch Biochem Biophys 2008;473(2):139-46. https://doi. org/10.1016/j.abb.2008.03.018, PMID:18395508

[49] Feng X, Teitelbaum SL. Osteoclasts: New Insights. Bone Res 2013;1(1):11-26. https://doi.org/10.4248/br201301003, PMID:26273491

[50] Raggatt LJ, Partridge NC. Cellular and molecular mechanisms of bone remodeling. J Biol Chem 2010;285(33):25103-8. https://doi.org/10.1074/jbc. r109.041087, PMID:20501658

[51] Devlin H, Ferguson MW. Alveolar ridge resorption and mandibular atrophy. A review of the role of local and systemic factors. Br Dent J 1991; 170(3):101-4. https://doi.org/10.1038/sj.bdj.4807427, PMID:2007065

[52] Jahangiri L, Devlin H, Ting K, Nishimura I. Current perspectives in residual ridge remodeling and its clinical implications: a review. J Prosthet Dent 1998;80(2):224-37. https://doi.org/10.1016/s0022-3913(98)70116-7, PMID:9710828
[53] Nielsen MM, Witherden DA, Havran WL. gammadelta T cells in homeostasis and host defence of epithelial barrier tissues. Nat Rev Immunol 2017;17(12):733-45. https://doi.org/10.1038/nri.2017.101, PMID:28920588

[54] Takiishi T, Fenero CIM, Camara NOS. Intestinal barrier and gut microbiota: Shaping our immune responses throughout life. Tissue Barriers 2017;5(4):e1373208. https://doi.org/10.1080/21688370.2017.1373208, PMID: 28956703

[55] Moutsopoulos NM, Konkel JE. Tissue-Specific Immunity at the Oral Mucosal Barrier. Trends Immunol 2018;39(4):276-87. https://doi.org/10.1016/j. it.2017.08.005, PMID:28923364

[56] Harrison OJ, Linehan JL, Shih HY, Bouladoux N, Han SJ, Smelkinson M, et al. Commensal-specific $T$ cell plasticity promotes rapid tissue adaptation to injury. Science 2019;363(6422). https://doi.org/10.1126/science.aat6280, PMID:30523076

[57] Hammad H, Lambrecht BN. Barrier Epithelial Cells and the Control of Type 2 Immunity. Immunity 2015;43(1):29-40. https://doi.org/10.1016/j.immuni.2015.07.007, PMID:26200011

[58] Nishimura I, Damiani PJ, Atwood DA. Resorption of residual ridges (RRR) in rats. J Dent Res 1987;66(12):1753-7. https://doi.org/10.1177/ 00220345870660121101, PMID:3479475

[59] Hokugo A, Christensen R, Chung EM, Sung EC, Felsenfeld AL, Sayre JW, et al. Increased prevalence of bisphosphonate-related osteonecrosis of the jaw with vitamin D deficiency in rats. J Bone Miner Res 2010;25(6):1337-49. https://doi.org/10.1002/jbmr.23, PMID:20200938

[60] Park S, Kanayama K, Kaur K, Tseng HC, Banankhah S, Quje DT, et al. Osteonecrosis of the Jaw Developed in Mice: DISEASE VARIANTS REGULATED BY gammadelta T CELLS IN ORAL MUCOSAL BARRIER IMMUNITY. J Biol Chem 2015;290(28):17349-66. https://doi.org/10.1074/jbc.m115.652305, PMID:26013832

[61] Lin Z, Fateh A, Salem DM, Intini G. Periosteum: biology and applications in craniofacial bone regeneration. J Dent Res 2014;93(2):109-16. https://doi. org/10.1177/0022034513506445, PMID:24088412

[62] Bisseret D, Kaci R, Lafage-Proust MH, Alison M, Parlier-Cuau C, Laredo JD, et al. Periosteum: characteristic imaging findings with emphasis on radiologic-pathologic comparisons. Skeletal Radiol 2015;44(3):321-38. https://doi.org/10.1007/s00256-014-1976-5, PMID:25269751

[63] Mohammadi A, Ilkhanizadeh B, Ghasemi-Rad M. Mandibular plasmocytoma with sun-ray periosteal reaction: A unique presentation. Int J Surg Case Rep 2012;3(7):296-8. https://doi.org/10.1016/j.ijscr.2012.02.009, PMID:22537974

[64] Charoenlarp P, Silkosessak-Chaiudom O, Vipismakul V. Atypical periosteal reaction and unusual bone involvement of ameloblastoma: A case report with 8-year follow-up. Imaging Sci Dent 2021;51(2):195-201. https://doi. org/10.5624/isd.20200264, PMID:34235065

[65] Baba A, Goto TK, Ojiri H, Takagiwa M, Hiraga C, Okamura M, et al. CT imaging features of antiresorptive agent-related osteonecrosis of the jaw/ medication-related osteonecrosis of the jaw. Dentomaxillofac Radiol 2018;47(4):20170323. https://doi.org/10.1259/dmfr.20170323, PMID:29365278

[66] Assili Z, Dolivet G, Salleron J, Griffaton-Tallandier C, Egloff-Juras C, Phulpin B. A Comparison of the Clinical and Radiological Extent of Denosumab (Xgeva((R))) Related Osteonecrosis of the Jaw: A Retrospective Study. J Clin Med 2021;10(11). https://doi.org/10.3390/jcm10112390, PMID:34071481

[67] Bierbaumer L, Schwarze UY, Gruber R, Neuhaus W. Cell culture models of oral mucosal barriers: A review with a focus on applications, culture conditions and barrier properties. Tissue Barriers 2018;6(3):1479568. https://doi.org/10.1080/21688370.2018.1479568, PMID:30252599

[68] Gomes RN, Manuel F, Nascimento DS. The bright side of fibroblasts: molecular signature and regenerative cues in major organs. NPJ Regen Med 2021;6(1):43. https://doi.org/10.1038/s41536-021-00153-z, PMID:34376677

[69] Seo BM, Miura M, Gronthos S, Bartold PM, Batouli S, Brahim J, et al. Investigation of multipotent postnatal stem cells from human periodontal ligament. Lancet 2004;364(9429):149-55. https://doi.org/10.1016/s01406736(04)16627-0, PMID:15246727

[70] Tsukasaki M. RANKL and osteoimmunology in periodontitis. J Bone Miner Metab 2021;39(1):82-90. https://doi.org/10.1007/s00774-020-01165-3, PMID:33070252

[71] Yang $\mathrm{CY}$, Jeon $\mathrm{HH}$, Alshabab A, Lee YJ, Chung CH, Graves DT. RANKL deletion in periodontal ligament and bone lining cells blocks orthodontic tooth movement. Int J Oral Sci 2018;10(1):3. https://doi.org/10.1038/s41368017-0004-8, PMID:29483595 
[72] Fujihara R, Usui M, Yamamoto G, Nishii K, Tsukamoto Y, Okamatsu Y, et al. Tumor necrosis factor-alpha enhances RANKL expression in gingival epithelial cells via protein kinase A signaling. J Periodontal Res 2014;49(4):50817. https://doi.org/10.1111/jre.12131, PMID:24102429

[73] Knoop KA, Kumar N, Butler BR, Sakthivel SK, Taylor RT, Nochi T, et al. RANKL is necessary and sufficient to initiate development of antigen-sampling $M$ cells in the intestinal epithelium. J Immunol 2009;183(9):5738-47. https:// doi.org/10.4049/jimmunol.0901563, PMID:19828638

[74] Sharma AK, Mirza FD. Palatal mucosa under dentures: a qualitative histologic and histochemical analysis. J Prosthet Dent 1986;56(5):574-82. https:// doi.org/10.1016/0022-3913(86)90424-5, PMID:2430097

[75] Jani RM, Bhargava K. A histologic comparison of palatal mucosa before and after wearing complete dentures. J Prosthet Dent 1976;36(3):254-60. https://doi.org/10.1016/0022-3913(76)90179-7, PMID:1066479

[76] Moutsopoulos NM, Moutsopoulos HM. The oral mucosa: A barrier site participating in tissue-specific and systemic immunity. Oral Dis 2018; 24(1-2):22-5. https://doi.org/10.1111/odi.12729, PMID:29480644

[77] Hasiakos S, Gwack Y, Kang M, Nishimura I. Calcium Signaling in T Cells and Chronic Inflammatory Disorders of the Oral Cavity. J Dent Res 2021;100(7):693-9. https://doi.org/10.1177/0022034521990652, PMID: 33541200

[78] Tsukasaki M, Takayanagi $H$. Osteoimmunology: evolving concepts in bone-immune interactions in health and disease. Nat Rev Immunol 2019; 19(10):626-42. https://doi.org/10.1038/s41577-019-0178-8, PMID:31186549

[79] Takayanagi H, Ogasawara K, Hida S, Chiba T, Murata S, Sato K, et al. Tcell-mediated regulation of osteoclastogenesis by signalling cross-talk between RANKL and IFN-gamma. Nature 2000;408(6812):600-5. https:// doi.org/10.1038/35046102, PMID:11117749

[80] Takayanagi H. Osteoimmunology: shared mechanisms and crosstalk between the immune and bone systems. Nat Rev Immunol 2007;7(4):292-304. https://doi.org/10.1038/nri2062, PMID:17380158

[81] Nakashima T, Wada T, Penninger JM. RANKL and RANK as novel therapeutic targets for arthritis. Curr Opin Rheumatol 2003;15(3):280-7. https://doi. org/10.1097/00002281-200305000-00016, PMID:12707582

[82] Roato I, Grano M, Brunetti G, Colucci S, Mussa A, Bertetto O, et al. Mechanisms of spontaneous osteoclastogenesis in cancer with bone involvement. FASEB J 2005;19(2):228-30. https://doi.org/10.1096/fj.04-1823fje, PMID:15550550

[83] Roato I, Caldo D, D'Amico L, D'Amelio P, Godio L, Patane S, et al. Osteoclastogenesis in peripheral blood mononuclear cell cultures of periprosthetic osteolysis patients and the phenotype of T cells localized in periprosthetic tissues. Biomaterials 2010;31(29):7519-25. https://doi.org/10.1016/j. biomaterials.2010.06.027, PMID:20638717

[84] Park H, Li Z, Yang XO, Chang SH, Nurieva R, Wang YH, et al. A distinct lineage of CD4 T cells regulates tissue inflammation by producing interleukin 17. Nat Immunol 2005;6(11):1133-41. https://doi.org/10.1038/ni1261, PMID:16200068

[85] Harrington LE, Hatton RD, Mangan PR, Turner H, Murphy TL, Murphy KM, et al. Interleukin 17-producing CD4+ effector T cells develop via a lineage distinct from the Thelper type 1 and 2 lineages. Nat Immunol 2005;6(11):112332. https://doi.org/10.1038/ni1254, PMID:16200070

[86] Sato K, Suematsu A, Okamoto K, Yamaguchi A, Morishita Y, Kadono Y, et al. Th17 functions as an osteoclastogenic helper T cell subset that links T cell activation and bone destruction. J Exp Med 2006;203(12):2673-82. https:// doi.org/10.1084/jem.20061775, PMID:17088434

[87] Sparber F, De Gregorio C, Steckholzer S, Ferreira FM, Dolowschiak T, Ruchti $\mathrm{F}$, et al. The Skin Commensal Yeast Malassezia Triggers a Type 17 Response that Coordinates Anti-fungal Immunity and Exacerbates Skin Inflammation. Cell Host Microbe 2019;25(3):389-403 e6. https://doi.org/10.1016/j. chom.2019.02.002, PMID:30870621

[88] Tan TG, Sefik E, Geva-Zatorsky N, Kua L, Naskar D, Teng F, et al. Identifying species of symbiont bacteria from the human gut that, alone, can induce intestinal Th17 cells in mice. Proc Natl Acad Sci U S A 2016;113(50):E8141-E50. https://doi.org/10.1073/pnas.1617460113, PMID:27911839

[89] Dutzan N, Abusleme L, Bridgeman H, Greenwell-Wild T, Zangerle-Murray T, Fife ME, et al. On-going Mechanical Damage from Mastication Drives Homeostatic Th17 Cell Responses at the Oral Barrier. Immunity 2017;46(1): 133-47. https://doi.org/10.1016/j.immuni.2016.12.010, PMID:28087239

[90] Jonsson D, Nebel D, Bratthall G, Nilsson BO. The human periodontal ligament cell: a fibroblast-like cell acting as an immune cell. J Periodontal Res 2011;46(2):153-7. https://doi.org/10.1111/j.1600-0765.2010.01331.x, PMID:21118418
[91] Beertsen W, McCulloch CA, Sodek J. The periodontal ligament: a unique, multifunctional connective tissue. Periodontol 2000 1997;13:20-40. https:// doi.org/10.1111/j.1600-0757.1997.tb00094.x, PMID:9567922

[92] Yashima Y, Kaku M, Yamamoto T, Izumino J, Kagawa H, Ikeda K, et al. Effect of continuous compressive force on the expression of RANKL, OPG, and VEGF in osteocytes. Biomed Res 2020;41(2):91-9. https://doi.org/10.2220/ biomedres.41.91, PMID:32307402

[93] Shoji-Matsunaga A, Ono T, Hayashi M, Takayanagi H, Moriyama K, Nakashima T. Osteocyte regulation of orthodontic force-mediated tooth movement via RANKL expression. Sci Rep 2017;7(1):8753. https://doi. org/10.1038/s41598-017-09326-7, PMID:28821826

[94] Sasaki F, Hayashi M, Ono T, Nakashima T. The regulation of RANKL by mechanical force. J Bone Miner Metab 2020. https://doi.org/10.1007/ s00774-020-01145-7, PMID:32889574

[95] Yamaguchi M. RANK/RANKL/OPG during orthodontic tooth movement. Orthod Craniofac Res 2009;12(2):113-9. https://doi.org/10.1111/j.1601-6343. 2009.01444.x, PMID:19419454

[96] Davies P, Bailey PJ, Goldenberg MM, Ford-Hutchinson AW. The role of arachidonic acid oxygenation products in pain and inflammation. Annu Rev Immunol 1984;2:335-57. https://doi.org/10.1146/annurev.iy.02.040184. 002003, PMID:6100476

[97] Yamasaki K, Miura F, Suda T. Prostaglandin as a mediator of bone resorption induced by experimental tooth movement in rats. J Dent Res 1980;59(10):1635-42. https://doi.org/10.1177/00220345800590101301, PMID: 6932420

[98] Kanzaki H, Chiba M, Shimizu Y, Mitani H. Periodontal ligament cells under mechanical stress induce osteoclastogenesis by receptor activator of nuclear factor kappaB ligand up-regulation via prostaglandin E2 synthesis. J Bone Miner Res 2002;17(2):210-20. https://doi.org/10.1359/jbmr. 2002.17.2.210, PMID:11811551

[99] Saito S, Ngan P, Rosol T, Saito M, Shimizu H, Shinjo N, et al. Involvement of PGE synthesis in the effect of intermittent pressure and interleukin-1 beta on bone resorption. J Dent Res 1991;70(1):27-33. https://doi.org/ 10.1177/00220345910700010401, PMID:1991858

[100] Ngan P, Saito S, Saito M, Lanese R, Shanfeld J, Davidovitch Z. The interactive effects of mechanical stress and interleukin-1 beta on prostaglandin $E$ and cyclic AMP production in human periodontal ligament fibroblasts in vitro: comparison with cloned osteoblastic cells of mouse (MC3T3-E1). Arch Oral Biol 1990;35(9):717-25. https://doi.org/10.1016/0003-9969(90) 90094-q, PMID:1965393

[101] Davidovitch Z, Shanfeld JL, Montgomery PC, Lally E, Laster L, Furst L, et al. Biochemical mediators of the effects of mechanical forces and electric currents on mineralized tissues. Calcif Tissue Int 1984;36 Suppl 1:S86-97. https://doi.org/10.1007/bf02406140, PMID:6204728

[102] Phusuntornsakul $P$, Jitpukdeebodintra S, Pavasant $P$, Leethanakul C. Vibration enhances PGE2, IL-6, and IL-8 expression in compressed hPDL cells via cyclooxygenase pathway. J Periodontol 2018;89(9):1131-41. https:// doi.org/10.1002/jper.17-0653, PMID:29761497

[103] Ullrich N, Schroder A, Jantsch J, Spanier G, Proff P, Kirschneck C. The role of mechanotransduction versus hypoxia during simulated orthodontic compressive strain-an in vitro study of human periodontal ligament fibroblasts. Int J Oral Sci 2019;11(4):33. https://doi.org/10.1038/s41368-0190066-x, PMID:31685804

[104] Cho JS, Han IH, Lee HR, Lee HM. Prostaglandin E2 Induces IL-6 and IL-8 Production by the EP Receptors/Akt/NF-kappaB Pathways in Nasal Polyp-Derived Fibroblasts. Allergy Asthma Immunol Res 2014;6(5):449-57. https://doi.org/10.4168/aair.2014.6.5.449, PMID:25229003

[105] Stanfeld J, Jones J, Laster L, Davidovitch Z. Biochemical aspects of orthodontic tooth movement. I. Cyclic nucleotide and prostaglandin concentrations in tissues surrounding orthodontically treated teeth in vivo. Am J Orthod Dentofacial Orthop 1986;90(2):139-48. https://doi.org/ 10.1016/0889-5406(86)90046-6, PMID:3017094

[106] Nishimura I, Szabo G, Flynn E, Atwood DA. A local pathophysiologic mechanism of the resorption of residual ridges: prostaglandin as a mediator of bone resorption. J Prosthet Dent 1988;60(3):381-8. https://doi. org/10.1016/0022-3913(88)90290-9, PMID:3262741

[107] Akashi Y, Nagasaki A, Okawa H, Matsumoto T, Kondo T, Yatani $H$, et al. Cyclic pressure-Induced cytokines from gingival fibroblasts stimulate osteoclast activity: clinical implications for alveolar bone loss in denture wearers. J Prosthodont Res; Online ahead of print. https://doi.org/10.2186/ jpr.JPR_D_21_00238 
[108] Campbell RL. A comparative study of the resorption of the alveolar ridges in denture-wearers and non-denture-wearers. J Am Dent Assoc 1960;60: 143-53. https://doi.org/10.14219/jada.archive.1960.0031, PMID:13807301

[109] Carlsson GE, Ragnarson N, Astrand P. Changes in height of the alveolar process in edentulous segments. II. A longitudinal clinical and radiographic study over 5 years of full upper denture patients with residual lower anteriors. Sven Tandlak Tidskr 1969;62(3):125-36. PMID:4897565

[110] Alsaggaf A, Fenlon MR. A case control study to investigate the effects of denture wear on residual alveolar ridge resorption in edentulous patients. J Dent 2020;98:103373. https://doi.org/10.1016/j.jdent.2020.103373, PMID: 32389732

[111] Pham NQ, Gonda T, Maeda Y, Ikebe K. Average rate of ridge resorption in denture treatment: A Systematic Review. J Prosthodont Res 2021;65(4):42937. https://doi.org/10.2186/jpr.jpr_d_20_00075, PMID:33281173

[112] Gendreau L, Loewy ZG. Epidemiology and etiology of denture stomatitis. J Prosthodont 2011;20(4):251-60. https://doi.org/10.1111/j.1532-849x.2011. 00698.x, PMID:21463383

[113] Szpaderska AM, Zuckerman JD, DiPietro LA. Differential injury responses in oral mucosal and cutaneous wounds. J Dent Res 2003;82(8):621-6. https://doi.org/10.1177/154405910308200810, PMID:12885847

[114] Schrementi ME, Ferreira AM, Zender C, DiPietro LA. Site-specific production of TGF-beta in oral mucosal and cutaneous wounds. Wound Repair Regen 2008;16(1):80-6. https://doi.org/10.1111/j.1524-475x.2007.00320.x, PMID:18086295

[115] Lin A, Hokugo A, Choi J, Nishimura I. Small cytoskeleton-associated molecule, fibroblast growth factor receptor 1 oncogene partner 2/wound inducible transcript-3.0 (FGFR1OP2/wit3.0), facilitates fibroblast-driven wound closure. Am J Pathol 2010;176(1):108-21. https://doi.org/10.2353/ ajpath.2010.090256, PMID:19959814

[116] Sukotjo C, Lin A, Song K, Ogawa T, Wu B, Nishimura I. Oral fibroblast expression of wound-inducible transcript 3.0 (wit3.0) accelerates the collagen gel contraction in vitro. J Biol Chem 2003;278(51):51527-34. https://doi. org/10.1074/jbc.m309616200, PMID:14527947

[117] Shannon DB, McKeown ST, Lundy FT, Irwin CR. Phenotypic differences between oral and skin fibroblasts in wound contraction and growth factor expression. Wound Repair Regen 2006;14(2):172-8. https://doi.org/10.1111/ j.1743-6109.2006.00107.x, PMID:16630106

[118] Von den Hoff JW. Effects of mechanical tension on matrix degradation by human periodontal ligament cells cultured in collagen gels. J Periodontal Res 2003;38(5):449-57. https://doi.org/10.1034/j.1600-0765.2003.00404.x, PMID:12941067

[119] Pitaru S, Soldinger M, Madgar D, Metzger Z. Bacterial endotoxin inhibits migration, attachment, and orientation of human gingival fibroblasts in vitro and delays collagen gel contraction. J Dent Res 1987;66(9):1449-55. https://doi.org/10.1177/00220345870660090801, PMID:3476617

[120] Nishimura I, Atwood DA. Knife-edge residual ridges: a clinical report. J Prosthet Dent 1994;71(3):231-4. https://doi.org/10.1016/0022-3913(94)90459-6, PMID:8164162

[121] Tambe A, Patil SB, Bhat S, Badadare MM. Cross-arch arrangement in complete denture prosthesis to manage an edentulous patient with oral submucous fibrosis and abnormal jaw relation. BMJ Case Rep 2014;2014. https://doi.org/10.1136/bcr-2013-203065, PMID:25239981
[122] Tseng HC, Kanayama K, Kaur K, Park SH, Park S, Kozlowska A, et al. Bisphosphonate-induced differential modulation of immune cell function in gingiva and bone marrow in vivo: role in osteoclast-mediated NK cell activation. Oncotarget 2015;6(24):20002-25. https://doi.org/10.18632/ oncotarget.4755, PMID:26343372

[123] Tsukasaki M, Komatsu N, Nagashima K, Nitta T, Pluemsakunthai W, Shukunami $C$, et al. Host defense against oral microbiota by bonedamaging $T$ cells. Nat Commun 2018;9(1):701. https://doi.org/10.1038/ s41467-018-03147-6, PMID:29453398

[124] AlSheikh HA, AlZain S, Shaik JP, Bhogoju S, Warsy A, Reddy Parine N. Two novel SNPs in genes involved in immune response and their association with mandibular residual ridge resorption. Saudi J Biol Sci 2020;27(3):84652. https://doi.org/10.1016/j.sjbs.2020.01.016, PMID:32127761

[125] Kim JH, Oh MY, Paek J, Lee J. Association between FGFR1OP2/wit3.0 polymorphisms and residual ridge resorption of mandible in Korean population. PLoS One 2012;7(8):e42734. https://doi.org/10.1371/journal.pone.0042734, PMID:22880093

[126] Suwanwela J, Lee J, Lin A, Ucer TC, Devlin H, Sinsheimer J, et al. A genetic association study of single nucleotide polymorphisms in FGFR1OP2/ wit3.0 and long-term atrophy of edentulous mandible. PLoS One 2011; 6(1):e16204. https://doi.org/10.1371/journal.pone.0016204, PMID:21283824

[127] Paek J, Oh Y, Kim J, Lee JH. Single nucleotide polymorphisms in HIFlalpha gene and residual ridge resorption (RRR) of mandible in Korean population. Gene Expr 2015;16(3):137-44. https://doi.org/10.3727/10522161 5x14181440065490, PMID:25700369

[128] Sundar SS, Jayesh SR, Hussain S. Association of matrix metalloproteinase 1 gene promoter mutation and residual ridge resorption in edentulous patients of South Indian origin. J Pharm Bioallied Sci 2015;7(Suppl 2): S652-5. https://doi.org/10.4103/0975-7406.163591, PMID:26538937

[129] lasella JM, Greenwell H, Miller RL, Hill M, Drisko C, Bohra AA, et al. Ridge preservation with freeze-dried bone allograft and a collagen membrane compared to extraction alone for implant site development: a clinical and histologic study in humans. J Periodontol 2003;74(7):990-9. https://doi. org/10.1902/jop.2003.74.7.990, PMID:12931761

[130] Rodd HD, Malhotra R, O'Brien CH, Elcock C, Davidson LE, North S. Change in supporting tissue following loss of a permanent maxillary incisor in children. Dent Traumatol 2007;23(6):328-32. https://doi.org/10.1111/j.16009657.2006.00466.x, PMID:17991231

[131] Aimetti M, Romano F, Griga FB, Godio L. Clinical and histologic healing of human extraction sockets filled with calcium sulfate. Int J Oral Maxillofac Implants 2009;24(5):902-9. PMID:19865631

[132] Schropp L, Wenzel A, Kostopoulos L, Karring T. Bone healing and soft tissue contour changes following single-tooth extraction: a clinical and radiographic 12-month prospective study. Int J Periodontics Restorative Dent 2003;23(4):313-23. https://doi.org/10.1016/j.prosdent.2003.10.022, PMID:12956475

[133] Yilmaz S, Efeoglu E, Kilic AR. Alveolar ridge reconstruction and/or preservation using root form bioglass cones. J Clin Periodontol 1998;25(10):832-9. https://doi.org/10.1111/j.1600-051x.1998.tb02378.x, PMID:9797057

This is an open-access article distributed under the terms of Creative Commons Attribution-NonCommercial License 4.0 (CC BY-

NC 4.0), which allows users to distribute and copy the material in any format as long as credit is given to the Japan Prosthodontic Society. It should be noted however, that the material cannot be used for commercial purposes. 